\title{
IMPLEMENTING TITLE IX: THE HEW REGULATIONS
}

Title IX of the Education Amendments of 1972, signed into law on June 23,1972 , prohibits sex discrimination in education. ${ }^{1}$ This provision was enacted in response to extensive hearings held by the House Special Subcommittee on Education, which documented nationwide sex discrimination in education. ${ }^{2}$ Senator Birch Bayh of Indiana urged his colleagues to take action in this area:

$[\mathrm{O}]$ ne of the great failings of the American educational system is the continuation of corrosive and unjustified discrimination against women. It is clear to me that sex discrimination reaches into all facets of educationadmissions, scholarship programs, faculty hiring and promotion, professional staffing, and pay scales. Indeed, the recent "Report on Higher Education"... . concluded,

Discrimination against women, in contrast to that against minorities, is still overt and socially acceptable within the academic community. ${ }^{3}$

The main provision of Title IX is an absolute prohibition, similar to that of Title VI of the Civil Rights Act of 1964:4 "No person in the United States shall, on the basis of sex, be excluded from participation in, be denied the benefits of, or be subjected to discrimination under any education program or activity receiving Federal financial assistance ...." Regulations implementing Title IX, promulgated by the Department of Health, Education, and Welfare, became effective on July $21,1975 .^{6}$

1 Act of June 23, 1972, Pub. L. No. 92-318, 36 Stat. 373, (codified at 20 U.S.C. $\S \S$ 1681-86 (Supp. II, 1972)).

${ }^{2}$ Hearings on $\$ 805$ of H.R. 16098 Before a Special Subcomm. of the House Comm. on Education and Labor, 91st Cong., 2d Sess. (1970) [hereinafter cited as 1970 Hearings].

3118 Cong. Rec. 5803 (1972) (remarks of Senator Bayh).

442 U.S.C. $\S 2000 d(1970)$.

${ }^{5} 20$ U.S.C. $\S 1681$ (a) (Supp. II, 1972). Title VI of the Civil Rights Act of 1964 forbids discrimination on the ground of race, color, or national origin in any program receiving federal financial assistance. 42 U.S.C. $\$ 2000 \mathrm{~d}(1970)$.

${ }^{6} 40$ Fed. Reg. 24128 (1975). HEW spent two years preparing the Title IX implementing regulations. On June 20,1974, the Office of Civil Rights presented its proposed regulations. 39 Fed. Reg. 22228 (1974). In order to accommodate the expected flood of reaction from educational institutions and women's groups, comments were accepted 
This comment will first develop from the legislative history, from executive and judicial interpretation of Titles VI and VII of the Civil Rights Act of $1964,{ }^{7}$ and from relevant constitutional adjudication, a framework with which to approach Title IX. The framework will then be applied to evaluate the HEW regulations as an implementation of the mandate of Title IX in the substantive areas of admissions and recruitment, access to classes and activities, behavior and appearance rules, use of marital or parental status, facilities, and athletics.

\section{The Statute}

The absolute prohibition of section 901(a) of Title IX, ${ }^{8}$ is followed by several exceptions relating to admissions. ${ }^{9}$ Section 901(a) applies only to vocational, professional and graduate schools, and public undergraduate schools. ${ }^{10}$ Public undergraduate schools that have had a continual tradition from their establishment of admitting only students of one sex are exempted from the prohibition against sex discrimination in admissions. ${ }^{11}$ Once a student is admitted, however, there can be no sex-based discrimination. ${ }^{12}$ Educational institutions run by religious organizations are exempted insofar as application of Title IX would be inconsistent with the religious tenets of the organization. ${ }^{13}$ A complete exemption from the statute is provided educational institutions whose primary purpose is training

through October 15, 1974. Id. 22231. Over 9,700 comments were received by the Department. 40 Fed. Reg. 24128 (1975).

742 U.S.C. $\$ \S 2000$ d, $2000 \mathrm{e}(1970)$.

${ }^{8} 20$ U.S.C. § 1681(a) (Supp. II, 1972); text accompanying note 5 supra.

${ }^{9} 20$ U.S.C. $\S \S 1 \overline{681}(\mathrm{a})(1)$, (5) (Supp. II, 1972):

(1) In regard to admissions to educational institutions, this section shall apply only to institutions of vocational education, professional education, and graduate higher education, and to public institutions of undergraduate higher education;

(5) In regard to admissions this section shall not apply to any public institution of undergraduate higher education which is an institution that traditionally and continually from its establishment has had a policy of admitting only students of one sex.

For a section by section analysis of the statute in light of its legislative history, see Buek \& Orleans, Sex Discrimination-A Bar to a Democratic Education: Overview of Title IX of the Education Amendments of 1972, 6 CoNN. L. REv. 1 (1973).

1020 U.S.C. $\$ 1681$ (a)(1) (Supp. II, 1972).

1120 U.S.C. § 1681(a)(5) (Supp. II, 1972); see Shelton \& Berndt, Sex Discrimination in

Vocational Education: Title IX and Other Remedies, 62 CALrF. L. REv. 1121 (1974).

12 HEW FACT SheET 3 (June, 1975).

1320 U.S.C. \& 1681(a)(3) (Supp. II, 1972). 
individuals for the military services. ${ }^{14}$ Section $901(\mathrm{~b})$ is an antiquota provision:

Nothing contained in subsection (a) of this section shall be interpreted to require any educational institution to grant preferential or disparate treatment to the members of one sex on account of an imbalance which may exist with respect to the total number or percentage of persons of that sex participating in or receiving the benefits of any federally supported program or activity, in comparison with the total number or percentage of persons of that sex in any community, State, section, or other area .... ${ }^{15}$

The only other exception to the absolute prohibition is section 907: "Notwithstanding anything to the contrary contained in this chapter, nothing contained herein shall be construed to prohibit any educational institution receiving funds under this Act, from maintaining separate living facilities for the different sexes." 16

On December 31, 1974, section $901^{17}$ was amended to exempt fraternities, sororities, and youth service organizations from the prohibitions of Title IX. ${ }^{18}$ The amendment resulted from the flood of objections received by $\mathrm{HEW}^{19}$ to section $86.31(\mathrm{~b})(7)$ of the proposed regulations, which would have left open the possibility of educational institutions losing their federal funds if found substantially to support an organization that discriminates by sex. ${ }^{20}$ This newest amendment and the admissions exemptions reflect the ambivalence of the Congress in its

${ }^{14} I d . \S 1681(\mathrm{a})(4)$.

${ }^{15}$ Id. $\S 1681$ (b).

${ }^{16} I d$. $\$ 1686$.

${ }^{17}$ Id. $\$ 1681$ (a).

${ }^{18}$ Act of Dec. 31,1974 , Pub. L. No. 93-568, § 3(a), 88 Stat. 1862, amending 20 U.S.C. $\S 1681$ (a) (Supp. II, 1972).

${ }^{19}$ N.Y. Times, Nov. 25,1974 , at 23 , col. 4 (city ed.).

2039 Fed.Reg. 22235 (1974):

86.31 Education programs and activities:

(b) [A] recipient shall not, on the basis of sex:

(7) Aid or perpetuate discrimination against any person by assisting any agency, organization, or person which discriminates on the basis of sex in providing any aid, benefit or service to students ....

Senator Bayh, the primary Senate sponsor of Title IX, 117 Cong. REc. 30155 (1971), proposed the new amendment to make explicit what he considered Congress' intent that the Act not extend to such organizations. 120 Cong. Rec. 21567-68 (daily ed. Dec. 16, 1974). There was no problem in getting it passed by the House, because a House conference report had attempted to achieve the same objective by generating legislative history 
attempt to abolish the most harmful effects of sex discrimination while responding to political pressure to keep the status quo in some areas. ${ }^{21}$

Section 902 of Title IX ${ }^{22}$ provides enforcement machinery identical to that of section 602 of Title VI of the Civil Rights Act of $1964,{ }^{23}$ but limited to education programs or activities. Each department and agency empowered to extend federal financial assistance is directed to issue rules and regulations to implement the statute. If after a hearing it is determined that a recipient is not complying with the rules and that future compliance cannot be effected on a voluntary basis, compliance may be enforced through termination of funds or refusal to grant further assistance. A department that takes such action must file a written report with the committees of the House and Senate having legislative jurisdiction over the program or activity involved. Judicial review is authorized by section $903,{ }^{24}$ again in language almost identical to that of Title VI. ${ }^{25}$

\section{Analysis of the Statute}

Discrimination against female students in education has taken many and varied forms. It has ranged from overt exclusion from particular classes such as shop, to more subtle discrimination such as inculcation of limited career orientations in female students. This diversity in modes of discrimination necessitates an assessment of the intended scope of Title IX. Is every classification by sex impermissible? Does the statute reach practices that are facially neutral but have a disparate effect on one sex? To what extent is separate but equal a permissible alternative?

to defeat HEW's interpretation of Title IX. 120 CoNG. REc. 11106-07 (daily ed. Nov. 26, 1974).

Representative Green of Oregon, the author of the statute, 117 Cong. REc. 9822 (1971), put into the Congressional Record on Nov. 26, 1974, the substance of the recommendation of the House conference report: "[Title IX] was never designed for the purpose of having the Federal Government intrude on private organizations and to force by Government fiat the integration of such groups as Boy Scouts, Girl Scouts, . . and all sororities and fraternities." 120 CoNG. Rec. 11106 (daily ed. Nov. 26, 1974) (remarks of Representative Green). Representative Green suggested other changes in the proposed HEW regulations that will be discussed below. See text accompanying notes 78-229 infra.

${ }^{21}$ See Buek \&e Orleans, supra note 9.

2220 U.S.C. § 1682 (Supp. II, 1972).

2342 U.S.C. $\$ 2000 \mathrm{~d}-1$ (1970).

${ }^{24} 20$ U.S.C. $\$ 1683$ (Supp. II, 1972).

${ }^{25} 42$ U.S.C. $\$ 2000 \mathrm{~d}-2(1970)$. 


\section{A. Overt Discrimination}

The practices most obviously covered by Title IX involve overtly different treatment of male and female students. Some elementary schools forbid girls to join the safety patrol. Colleges and universities often prescribe earlier curfews for women than for men. Vocational interest tests have been color coded pink and blue with different career choices for women and men. All of these are examples of explicit discrimination based on sex, prohibited by Title IX. Educational institutions should not be allowed to justify such overtly different treatment. When schools make explicit rules according to sex, Title IX's prohibition should be applied absolutely, with a narrow reading of section 907's "living facilities" exception. ${ }^{26}$

The legislative history of the statute is not particularly instructive on this interpretive question. Most of the congressional debate focused on the admissions exceptions that eventually became part of Title IX. ${ }^{27}$ At one point in the debates, however, Senator Bayh referred to Title IX as a "narrower embodiment" of the Equal Rights Amendment (ERA), which Congress had recently sent to the states for ratification. ${ }^{28}$ The Senate Report on the ERA interprets it as an absolute prohibition of overtly different treatment on the basis of sex. ${ }^{29}$ No justification by a state would be accepted for overtly disparate treatment under the ERA, and none should be accepted under Title IX.

Executive construction of Title VI of the Civil Rights Act of $1964,{ }^{30}$ forbidding discrimination on the basis of race, color, or national origin in any program receiving federal financing, also supports an absolute reading of the statute. ${ }^{31}$ Caution should be exercised, however, since Congress did not limit the effect of Title VI in any way, whereas Title IX has elaborate admissions exemptions and a living facilities exception. Congress obviously does not see race and sex discrimination in exactly the same way. One cannot conceive that Congress would enact a statute allowing higher admissions standards for blacks than whites in the interest of permitting educational institutions to determine the optimal environment for learning. Nor could money be allotted

2620 U.S.C. $\S 1686$ (Supp. II, 1972).

${ }^{27}$ See, e.g. 118 CoNG. REC. 5812-15 (1972); 117 id. 30408-12, 39248-61 (1971).

${ }^{28} 117$ CONG. REc. 30414 (1971) (remarks of Senator Bayh).

${ }^{29}$ S. REP. No. 689, 92d Cong., 2d Sess. 2 (1972); see Brown, Emerson, Falk \& Freedman, The Equal Rights Amendment: A Constitutional Basis for Equal Rights for Women, 80 YALE L.J. 871 (1971) [hereinafter cited as Brown].

${ }^{30} 42$ U.S.C. $\$ \S 2000 \mathrm{~d}$ et seq. (1970).

${ }^{31} \mathrm{See} 45$ C.F.R. $\S 80.3$ (1974). 
to a state system of education in which one school specializing in engineering and science admitted whites only, while another school, set up for blacks, taught only auto mechanics and maintenance work. That is just what the admission exemptions in Title IX allow. Nevertheless, it should not be assumed that because Congress was willing to write in certain exemptions, it did not intend the statute absolutely to prohibit overt sex-based discrimination in the areas not excepted. One might ask whether differences in treatment allowed by the HEW regulations to Title IX would be valid under Title VI, and, if not, whether sex should be viewed differently from race in that particular situation.

An absolute reading of the statute must take account of section 907, which allows "separate living facilities for the different sexes." 32 The term "living facilities" may include restrooms, lockers, and other school areas where disrobing takes place; but to extend the term any further would frustrate Congress' attempt to give women equal educational opportunity. ${ }^{33} \AA$ narrow reading of section 907 also conforms to the privacy exception to the ERA, on which much of the legislative history of that amendment is premised. ${ }^{34}$ The source of this implied exception is the constitutional right of privacy enunciated by the Supreme Court in Griswold v. Connecticut ${ }^{35}$ and Roe v. Wade. ${ }^{36}$ The Senate Report on the ERA indicates that the right of privacy exception extends only to separate restrooms and sleeping quarters. ${ }^{37}$ Such should also be the limit of the explicit exception of section 907 of Title IX.

The narrow reading given to the "bona fide occupational qualification" (BFOQ) exception to Title VII of the Civil Rights Act of $1964^{38}$ also supports a similar approach under Title IX. Title VII forbids discrimination in employment on the basis of race, color, religion, sex, or national origin. ${ }^{39}$ Such discrimination may be made, however, "in those certain instances where

3220 U.S.C. § 1686 (Supp. II, 1972).

${ }^{33}$ Support for a narrow reading of the exception can be found in the Supreme Court's construction of the Fair Labor Standards Act $\S 13(a)(2), 29$ U.S.C. § 213(a)(2) (1970), in A.H. Phillips, Inc. v. Walling, 324 U.S. 490 (1945). "To extend an exemption to other than those plainly and unmistakably within its terms and spirit is to abuse the interpretive process and to frustrate the announced will of the people." Id. at 493.

${ }^{34}$ See note 29 supra \& accompanying text.

35381 U.S. 479 (1965).

${ }^{36} 410$ U.S. 113 (1973).

${ }^{37}$ See note 29 supra \& accompanying text.

3842 U.S.C. $\$ 2000 \mathrm{e}-2$ (e) (1970).

${ }^{39} I d . \S 2000 \mathrm{e}-2$. 
religion, sex, or national origin is a bona fide occupational qualification reasonably necessary to the normal operation of that particular business or enterprise." ${ }^{40}$ In Title VII as in Title IX, a general prohibition is qualified by a single exception.

Both the courts and the Equal Employment Opportunity Commission have allowed very few employers to justify different treatment based explicitly on sex under the BFOQ exception. One court held that "sexual characteristics, rather than characteristics that might, to one degree or another, correlate with a particular sex" are the only basis for applying the BFOQ exception. ${ }^{41}$ Thus, wet nurses and sperm donors are two of the few occupations that would fit such a narrow reading. Another court imposed on the employer the "burden of proving that he had reasonable cause to believe, that is, a factual basis for believing, that all or substantially all women would be unable to perform safely and efficiently the duties of the job involved."42

In summary, the legislative histories of Title IX and of the ERA and executive and judicial construction of Titles VI and VII support an analysis of Title IX which absolutely proscribes explicitly different treatment of students according to sex, except in the area of living facilities.

\section{B. Facially Neutral Regulations Having a Discriminatory Effect}

Some school policies and regulations do not refer explicitly to male and female students and thus appear to be nondiscriminatory. Their effect, however, often is to burden female students. Restrictions on part-time attendance at colleges or universities is an example. Although applicable to men and women, women with young children feel the impact of this policy much more than male students, because of the inadequacy of child care facilities in this country. Schools often follow admissions policies that give preference to students from certain schools. If those schools are single-sex institutions, the college in effect discriminates against the sex excluded from the favored single-sex institution.

Title IX is broad enough to cover facially neutral practices having a disparate impact on women. However, the educational institutions should be allowed to justify the necessity of such practices in relation to the objectives of the educational program.

\footnotetext{
${ }^{40} I d . \S 2000 \mathrm{e}-2(\mathrm{e})(1)$.

41 Rosenfeld v. Southern Pac. Co., 444 F.2d 1219, 1225 (9th Cir. 1971).

42 Weeks v. Southern Bell Tel. \& Tel. Co., 408 F.2d 228, 235 (5th Cir. 1969).
} 
Such an interpretation of the statute is supported by parallel decisions under Titles VI and VII of the Civil Rights Act of $1964 .{ }^{43}$ In Griggs v. Duke Power Co., ${ }^{44}$ the Supreme Court examined neutrally stated employment procedures that were found disproportionately to disqualify blacks. The Court held that the requirement of a high school education or the passing of a standardized general intelligence test as a condition of employment could be sustained only if it had a "manifest relationship" to success in the job. ${ }^{45}$ Lack of discriminatory intent was irrelevant; the effect of the policy triggered application of Title VII.

A similarly broad definition of discrimination was applied in Lau $v$. Nichols. ${ }^{46}$ In Lau, Chinese speaking students alleged that the school system violated their rights under Title VI by failing to teach them English. The Court decided that regardless of intent, this failure amounted to discrimination based on national origin prohibited by Title VI. As in Griggs, effect was all important. It was not enough that all students were provided with the "same facilities, textbooks, teachers, and curriculum, for students who do not understand English are effectively foreclosed from any meaningful education." ${ }^{47}$ Lau and Griggs both suggest that a facially neutral requirement that is applied to all candidates for admission to a school or activity will be held to be discriminatory if its effect is to burden a protected group. ${ }^{48}$ Thus even facially neutral policies and regulations may be within the regulatory power of HEW under Title IX. A rule or practice having a disparate impact on women should be allowed only if the school shows "educational necessity"- that the goal sought by the facially neutral but effectively discriminatory rule cannot be achieved in any other manner.

\section{Regulations Concerning Unique Physical Characteristics}

Schools sometimes enact rules based on physical characteristics unique to one sex or the other. It must be asked whether, and if so, under what circumstnaces, Title IX forbids such rules. Pregnancy is usually the characteristic at issue. Both the Equal

\footnotetext{
4342 U.S.C. $\$ \S 2000 \mathrm{~d}, 2000 \mathrm{e}(1970)$.

44401 U.S. 424 (1971).

45 Id. at 432 .

46414 U.S. 563 (1974).

47414 U.S. at 566.

${ }^{48}$ See text accompanying notes 44-46 supra.
} 
Employment Opportunity Commission regulations under Title VII, ${ }^{49}$ and the HEW regulations implementing Title IX, ${ }^{50}$ apply to various practices of employers and schools relative to pregnant women. A federal district court recently held that an employer's disparate treatment of pregnant employees was not cognizable under Title VII. ${ }^{51}$ In so holding the court relied on footnote twenty in Geduldig v. Aiello, ${ }^{52}$ where the Supreme Court, in holding that California's disability insurance program did not violate the equal protection clause, rejected the contention that the pregnancy classification there involved was sex-based. The district court considered the definition of discrimination based on sex to be the same under the fourteenth amendment and under Title VII, and therefore considered itself bound by the Supreme Court's analysis in Aiello. ${ }^{53}$

On appeal, the Second Circuit rejected the district court's analysis, admonishing the court for reading the Aiello language out of the factual context in which it was used, ${ }^{54}$ and holding that in implementing Title VII the Equal Employment Opportunity Commission is not bound by the narrow fourteenth amendment definition of sex-based classifications suggested in Aiello. ${ }^{55}$ This broader view is consistent with the approach taken in Lau and Griggs. ${ }^{56}$ Justice Stewart, in his concurring opinion in Lau, indicated that although section 601 of Title VI, standing alone, might not have called for a judgment against the school districts, HEW interpretations of the section required the decision. ${ }^{57} \mathrm{He}$ relied on an earlier decision of the Court to hold "that the validity of a regulation promulgated under a general authorization provision such as $\S 602$ of Title VI 'will be sustained so long as it is reasonably related to the purposes of the

4929 C.F.R. $\$ 1604.10$ (1974).

5040 Fed. Reg. 24137-44 (1975); see text accompanying notes 170-81 infra.

${ }^{51}$ Communications Workers of America v. American Tel. \& Tel. Co., 379 F. Supp. 679 (S.D.N.Y. 1974), rev'd, 513 F.2d 1024 (2d Cir. 1975), petition for cert. filed, 44 U.S.L.W. 3067 (U.S. June 19, 1975) (No. 74-1601).

32417 U.S. $484,496-97$ n.20 (1974).

53379 F. Supp. at 682.

${ }^{54}$ Communications Workers of America v. American Tel. \& Tel. Co., 513 F.2d 1024, 1028-30 (2d Cir. 1975), petition for cert. filed, 44 U.S.L.W. 3067 (U.S. June 19, 1975) (No. 74-1601).

${ }^{55}$ Id. at 1030-32. "There is," the court noted, "no requirement that the discriminatory practices forbidden by this statute should be limited to practices violative of the Equal Protection Clause. Practices forbidden by Title VII and the EEOC guidelines issued thereunder may, nonetheless, be able to survive Equal Protection attack." Id. at 1031 .

${ }^{56}$ See text accompanying notes 44-48 supra.

57414 U.S. at 570-71 (Stewart, J., concurring). 
enabling legislation." "58 In Griggs, the Court noted that such agency interpretations are entitled to "great deference."

This criterion should also be used to evaluate the regulations issued under Title IX. What the Court said in Aiello in the context of fourteenth amendment litigation should not limit HEW's attempt to enforce remedial legislation. That a pregnancy classification is not sex-based for fourteenth amendment purposes does not foreclose the constitutional claim, but merely shifts the analysis from the greater burden of justification required for sex-based discrimination by Reed $v$. Reed ${ }^{60}$ and Frontiero $v$. Richardson ${ }^{61}$ to the traditional "rational basis" analysis. ${ }^{62}$ In the same way, such classifications will be examined under Title IX and will be permitted if educational necessity can be demonstrated. But the failure of a pregnancy classification to constitute a sex-based classification for fourteenth amendment purposes and the possibility that it can be justified by a showing of educational necessity should not be relevant to the initial question of the cognizability under Title IX of an attack on the regulation.

\section{The Separate But Equal Doctrine}

Pervading the statutory analysis suggested above is the spectre of the "separate but equal" doctrine. When may an educational institution fulfill its obligations under Title IX by providing separate but equal programs or activities? Proponents of the ERA suggest that under that amendment there is no place for separate but equal. "It would simply operate to perpetuate a dual system of equality, different but not equal. Essentially the

${ }^{58}$ Id. at 571 (quoting Mourning v. Family Publications Service, Inc., 411 U.S. 356, 369 (1973) (footnote omitted)).

${ }^{59} 401$ U.S. at 434. In Communications Workers of America v. American Tel. \& Tel. Co., 513 F.2d 1024 (2d Cir. 1975), petition for cert. filed, 44 U.S.L.W. 3067 (U.S. June 19, 1975) (No. 74-1601), the Second Circuit in part relied on the deference to be accorded agency interpretations of its statutory mandate to hold that the Supreme Court had not intended, contrary to the district court's holding, to imply that is Aiello footnote would invalidate EEOC regulations broader than the narrow fourteenth amendment definition of sex-based discrimination there articulated. 513 F.2d at 1030.

Bo 404 U.S. 71 (1971).

61411 U.S. 677 (1973).

62 In Reed v. Reed, 404 U.S. 71 (1971), the Supreme Court invalidated a state statute that gave an automatic preference to males in granting letters of administration. Evidencing a sensitivity to the sex classification without finding it a "suspect" classification, the Court found the statute to be without rational basis. Frontiero v. Richardson, 411 U.S. 677 (1973), struck down federal statutes wherein the procedures for claiming one's spouse as a dependent varied between servicemen and servicewomen. Four members of the Court found sex a "suspect" classification while three did not reach that issue since they found the scheme irrational under traditional equal protection analysis. 
separate-but-equal doctrine is a device for keeping one group in a subordinate position. . . Experience has shown, furthermore, that in practice separate-but-equal is rarely in fact equal." ${ }^{33}$ If it can be shown that a separate program is not equal, there is no question that Title IX is violated. Where the tangible aspects of separate programs for females and males are arguably equal, however, the long tradition of separation of the sexes militates against an automatic rejection of the concept.

An attempt to assess the place of separate but equal under Title IX must begin by looking to the analysis of Brown v. Board of Education ${ }^{64}$ that caused the Supreme Court to denounce separation of the races. It might be argued that separation of the sexes is not based on a judgment of inferiority, as was racial segregation, but rather on a conception of the different, complementary roles of women and men. It is, however, just that assumption and inculcation of role that is at the heart of sex discrimination in education. ${ }^{65}$ Only recently has this "equalitarian veneer" been put on the system that has channeled women into a single career while men have been encouraged to reach their educational and career potentials. ${ }^{66}$ In addition to effect on motivation is the even sadder loss of self-esteem occasioned by sex segregation. One elementary school girl wrote in a letter: "Dear God, Are boys better than girls? I know you are one, but please try to be fair." ${ }^{\text {"67 }}$ Although this sense of inferiority and development of sex roles has taken place frequently in integrated environments, it is certainly exacerbated by overt separation.

It has been suggested that Supreme Court cases antedating Brown might be used for guidance in evaluating separate activities within schools. In Sweatt $v$. Painter, ${ }^{68}$ the Court ordered the University of Texas Law School to admit a black student because its legal education was superior to that of a state law school established for blacks.

[T] ] University of Texas Law School possesses to a far greater degree those qualities which are incapable of

${ }^{63}$ Brown, supra note 29, at 902.

64347 U.S. 483 (1954).

${ }^{65}$ See, e.g., Bem \& Bem, Case Study of a Nonconscious Ideology: Training the Woman to Know Her Place, printed in 1970 Hearings, supra note 2, at 1042; Comment, Teaching Woman Her Place: The Role of Public Education in the Development of Sex Roles, 24 Hastings L.J. 1191 (1973).

${ }^{66}$ See Bem \& Bem, supra note 65, at 1043.

67 Comment, supra note 65 , at 1191 .

68339 U.S. 629 (1950). 
objective measurement but which make for greatness in a law school. Such qualities, to name but a few, include reputation of the faculty, experience of the administration, position and influence of the alumni, standing in the community, traditions and prestige ${ }^{69}$

The decision of McLaurin v. Oklahoma State Regents ${ }^{70}$ also involved the separate but equal doctrine, but within a single educational institution. The Court held that forcing a black student to sit apart in the classroom, cafeteria, and library impaired "his ability to study, to engage in discussions and exchange views with other students ...."71 Buck and Orleans, HEW lawyers, consider these cases "entirely apposite to Title IX."72

They dictate that where separate treatment on the basis of sex is proposed by an entity subject to Title IX, all indicia must indicate that full experiential equality is accorded those who will be affected. Put slightly differently, the treatment proposed must be such as demonstrably would not affect a student or employee's "free choice" among the separate activities, were sex not a factor.

... In the multitude of practices subject to this provision, simply the possibility of substantive inequalities, including those derived from the fact of isolation itself, gives rise to a presumption against separate treatment. ${ }^{73}$

If Title IX is to have its intended remedial effect there must be a presumption against separate treatment of females and males. The reasons asserted for the separate treatment should be relevant to a determination of its acceptability uder Title IX. One reason that might be asserted as a justification for separate treatment is the explicit living facilities exception of section $907,{ }^{74}$ or what the educational entity might think a proper ex: tension of that exception. Also, separate but equal treatment might be necessary at times to forestall an attack by female students under Lau and Griggs. ${ }^{75}$ For example, it could be argued that opening all competitive athletic teams to female students

\footnotetext{
${ }^{69} \mathrm{Id}$. at 634 .

70339 U.S. 637 (1950).

71 Id. at 641 .

72 Buek \& Orleans, supra note 9, at 19.

${ }^{73} \mathrm{Id}$.

7420 U.S.C. § 1686 (Supp. II, 1972).

${ }^{75}$ See text accompanying notes $44-48$ supra.
} 
without any separate athletic program for them would effectively shut out the great majority of women from competitive athletics. They would then receive less benefits than their male counterparts in much the same way as the Chinese-speaking students were discriminated against in $\mathrm{Lau}^{76} \mathrm{~A}$ final possible reason school officials might advance for separate programs is the belief that girls learn differently than boys and, therefore, need different environments in which to reach their potentials. Educational authorities could be marshalled on both sides of this issue in the same way the medical authorities contradicted each other in the early sports cases. ${ }^{77}$ Because of the risk that young girls will be channelled into a stereotype of one preparing for very limited future activity and will thereby suffer the sense of inferiority noted in Brown, this last rationale should be accorded no place under Title IX.

Separate but equal treatment should be permitted only when an educational entity is within the narrowly interpreted living facilities exception discussed above, or when there is proof that without a separate activity, female students will be, in effect, foreclosed from meaningful particpation in the activity and thus discriminated against in the sense recognized in Lau.

\section{The Regulations}

The principles developed in the preceding paragraphs provide a framework against which to assess the effectiveness of regulations promulgated by $\mathrm{HEW}$ as an implementation of the policy of Title IX. The regulations, finalized as Part 86 of Title 45 of the Code of Federal Regulations, ${ }^{78}$ consist of Subparts A through F. ${ }^{79}$ This Comment will not deal with Subpart E (Discrimination on the Basis of Sex in Employment in Educational Programs) ${ }^{80}$ or with Subpart F (Procedures). ${ }^{81}$ The discussion will focus on Subparts C (Admission and Recruitment) ${ }^{82}$ and D (Discrimination in Programs and Activities), ${ }^{83}$ both of which re-

${ }^{76}$ See text accompanying notes 207-08 infra.

${ }^{77}$ Compare Fortin v. Darlington Little League, Inc., 376 F. Supp. 473 (D.R.I. 1974), rev'd, 514 F.2d 344 (1st Cir. 1975) and Magill v. Avonworth Baseball Conference, 364 F. Supp. 1212 (W.D. Pa. 1973), vacated, 497 F.2d 921 (3d Cir. 1974), with NOW, Essex County Chapter v. Little League Baseball, Inc., 127 N.J. Super. 522, 318 A.2d 33 (1974).

${ }^{78} 40$ Fed. Reg. 24128-24145 (1975).

${ }^{79}$ Id. 24137.

${ }^{80} I d .24143-44$.

${ }^{81}$ Id. 24144. For proposed consolidated procedural regulations for Title IX and other civil rights laws see $i d$. 24148.

${ }^{82}$ Id. 24140.

${ }^{83}$ Id. $24140-43$. 
late directly to the treatment of students. The introductory and coverage sections will be examined only briefly.

\section{A. Subparts $A$ and B: Introduction and Coverage}

The introduction to the regulations defines terms and explains when remedial and affirmative action and assurances of compliance are required. ${ }^{84}$ Most of the section is a straightforward application of the statute. The coverage regulations also adhere closely to the statute and, therefore, are not a source of controversy. The coverage section establishes procedures to assure that the section 901 (a)(3) $)^{85}$ exemption for educational institutions of religious organizations is narrowly limited. If a religious institution wishes to claim that certain guidelines are inconsistent with its religious tenets, it must set forth in writing to the Director of the Office for Civil Rights the extent of the requested exemption and a copy of the religious tenets under which the exemption is claimed.86

\section{B. Subpart C: Admission and Recruitment}

After a general prohibition of sex discrimination in admissions, Subpart $\mathrm{C}$ delineates specific prohibitions such as ranking separately on the basis of sex, and the use of quotas. ${ }^{87}$ The use of separate rankings of male and female applicants as a means to enforce higher admissions standards for women has been attacked successfully under the rational basis test of the equal protection clause of the fourteenth amendment. ${ }^{88}$ This is a blatant form of admissions discrimination and certainly violates Title IX. The quota system was specifically mentioned in the legislative history as a practice prohibited by the statute..$^{89}$

In language similar to that used by the Court in Griggs, ${ }^{90}$ the regulations forbid the use of

any test or other criterion for admission which has a disproportionately adverse effect on persons on the

${ }^{84}$ Id. 24137-39.

8520 U.S.C. $\$ 1681$ (a)(3) (Supp. II, 1972).

8640 Fed. Reg. 24139 , § 86.12 (1975).

${ }^{87}$ Id. 24140, § 86.21(a), (b).

${ }^{88}$ In Bray v. Lee, 337 F. Supp. 934 (D. Mass. 1972), the Boston Latin School was forbidden to demand higher admission test scores from girls than from boys. Berkelman v. San Francisco Unified School Dist., 501 F.2d 1264 (9th Cir. 1974), disallowed the same practice by a college preparatory high school.

${ }^{89}$ See, e.g., 118 Cong. Rec. 5812 (1972) (remarks of Senator Beall).

${ }^{90}$ Text accompanying note 44 supra. 
basis of sex unless the use of such test or criterion is shown to predict validly success in the education program or activity in question and alternative tests or criteria which do not have such a disproportionately adverse effect are shown to be unavailable. ${ }^{91}$

The regulations do not prohibit other practices neutral on their face but having a disparate impact on the protected class, such as restrictions on age or part-time attendance. The Women's Equity Action League and Representative Bella Abzug prepared a preliminary analysis of the regulations, ${ }^{92}$ recommending prohibition of such policies. ${ }^{93} \mathrm{~A}$ broader attack on such procedures is within HEW's province and would increase the effectiveness of the regulations in eradicating all forms of sex discrimination in admissions.

Also forbidden in admissions procedures is any rule or policy concerning marital or parental status of students which operates to exclude members of one sex. ${ }^{94}$ Pregnancy and related conditions are to be treated as any other temporary disability or physical condition. ${ }^{95}$ According to the analysis suggested above, rules dealing with pregnancy should be considered within the regulatory power of $\mathrm{HEW}$ even though based on a physical characteristic unique to one sex..$^{96}$ The school must show educational necessity to justify different treatment of pregnant women. Such a showing probably cannot be made with respect to admissions policies that discriminate on the basis of marital or parental status.

Section 86.22 covers another method by which sex discrimination has been achieved in admissions. It prohibits schools from giving "preference to applicants for admission, on the basis of attendance at any educational institution ... which admits as students predominantly members of one sex, if the giving of such preference has the effect of discriminating on the basis of

9140 Fed. Reg. 24140, \& 86.21(b)(2) (1975).

92 Weal-Aazug Preliminary Analysis of Proposed Title IX Regulations, reprinted in 120 Cong. Rec. E 4863-69 (daily ed. July 18, 1974).

${ }^{93}$ Id. 4865.

9440 Fed. Reg. 24140, $\$ 86.21$ (c) (1975). Perhaps enforcement of this regulation could be facilitated by providing that requests for information concerning marital or parental status cannot be included on applications for admission.

${ }^{95} I d$. $\$ 86.21$ (c)(3): "A recipient . . . shall treat disabilities related to pregnancy, childbirth, termination of pregnancy, or recovery therefrom in the same manner and under the same policies as any other temporary disability or physical condition ...."

${ }^{96}$ See text accompanying notes 49-62 supra. 
sex ...."97 However, the introductory remarks put a gloss on the section.

Such preferences may be permissible ... if the granting institution can show that the pool of applicants eligible for such preferences includes roughly equivalent numbers of males and females, or if it can show that the total number of applicants eligible to receive preferences is insignificant in comparison with its total applicant pool. ${ }^{98}$

The subpart on admissions ends with a command that recruitment be directed equally to both sexes and a warning against primary or exclusive recruitment from single-sex or predominantly single-sex institutions. ${ }^{99}$

\section{Subpart D: Programs and Activities}

\section{Education Programs and Activities}

Subpart D of the regulations, containing the substantive guidelines for treatment of students within the schools, is the principal focus of this Comment. It should be emphasized that the subpart $D$ regulations apply to all educational institutions receiving federal financial assistance; the admissions exemptions stop once the student is accepted. ${ }^{100} \mathrm{~A}$ general prohibition of discrimination under any "academic, extracurricular, research, occupational training, or other educational program or activity," is followed by specific prohibitions. ${ }^{101}$ Neither aid, benefit, nor service can be denied, or given in a different manner or under a

9740 Fed. Reg. 24140, § 86.22 (1975); see id. $\$ 86.23(\mathrm{~b})$.

${ }^{88}$ Id. 24130.

${ }^{99}$ Id. 24140, \& 86.23.

${ }^{100}$ See text accompanying notes 9-12 supra.

10140 Fed. Reg. 24140-41, §§ 86.31(a), (b) (1975):

86.31 Education programs and activities.

(a) General. Except as provided elsewhere in this part, no person shall, on the basis of sex, be excluded from participation in, be denied the benefits of, or be subjected to discrimination under any academic, extracurricular, research, occupational training, or other education program or activity operated by a recipient which receives or benefits from Federal financial assistance. This subpart does not apply to actions of a recipient in connection with admission of its students to an education program or activity of (1) a recipient to which Subpart C does not apply, or (2) an entity, not a recipient, to which Subpart C would not apply if the entity were a recipient.

(b) Specific prohibitions. Except as provided in this subpart, in providing any aid, benefit, or service to a student, a recipient shall not, on the basis of sex:

(1) Treat one person differently from another in determining whether 
different set of requirements, on the basis of sex. ${ }^{102}$ All clubs and service organizations conducted by the school must be open to women and men. Girls must be allowed to participate in such activities as safety patrol. ${ }^{103}$ Recreational opportunities also must be equalized. The following practices are open to attack under these guidelines.

At one Ohio institution a woman could not use the handball courts unless a male signed up for her.

At a large midwestern university, the intramural pool was specifically reserved for "Faculty, Administrative Staff and Male Students" for approximately two hours each day. That is, this was a time for men only. ${ }^{104}$

An educational institution may not on the basis of sex "[s]ubject any person to separate or different rules of behavior, sanctions or other treatment."105 No longer may a school have different curfew requirements for women and men. Such regulations previously withstood equal protection challenges. ${ }^{106}$

such person satisfies any requirement or condition for the provision of such aid, benefit, or service;

(2) Provide different aid, benefits, or services or provide aid, benefits, or services in a different manner;

(3) Deny any person any such aid, benefit, or service;

(4) Subject any person to separate or different rules of behavior, sanctions, or other treatment;

(5) Discriminate against any person in the application of any rules of appearance;

(6) Apply any rule concerning the domicile or residence of a student or applicant, including eligibility for in-state fees and tuition;

(7) Aid or perpetuate discrimination against any person by providing significant assistance to any agency, organization, or person which discriminates on the basis of sex in providing any aid, benefit or service to students or employees;

(8) Otherwise limit any person in the enjoyment of any right, privilege, advantage, or opportunity.

${ }^{102}$ Id. $\S \S 86.31$ (b)(1), (2), (3).

${ }^{103}$ For a discussion of recommended changes in this area and others, see $K$. Davidson, R. Ginsburg \& H. Kay, Text, Cases, and Materials on Sex-Based Discrimination (1974) [hereinafter cited as Davidson].

104 Project on the Status and Education of Women, What Constitutes Equality for Women in SPORT? 5 (April, 1974).

10540 Fed. Reg. 24141, § 86.31(b)(4) (1975).

${ }^{106}$ An attack on such a regulation under the equal protection clause failed in Robinson v. Board of Regents, 475 F.2d 707 (6th Cir. 1973), cert. denied, 416 U.S. 982 (1974), in which the Sixth Circuit found a rational relationship between the regulation and the State's legitimate safety objective. However, it is arguable that even under present equal protection standards, such a regulation should fall. Although the objective of protecting female students is commendable and to be encouraged, such a sweeping regulation goes beyond the Reed test of a "substantial relation to the object of the legislation." Reed v. Reed, 404 U.S. 71, 76 (1971). When a right as important as freedom of movement is at stake and the rule is so over-inclusive, the school should be required to pursue its 
Also specifically forbidden is discrimination "in the application of any rules of appearance."107 Presumably girls must now be allowed to wear pants, and boys must be permitted to wear their hair as long as they wish. It is difficult to know how much further the rule will or should go. In analogous Title VII litigation, courts have struck down differing rules for hair length but have sustained those for beards. ${ }^{108}$ Since women cannot grow beards, they were considered a sex-specific characteristic and not within the purview of the statute. This Comment contends, however, that all "appearance" rules should be scrutinized under Title IX, but should be allowed to stand if educational necessity can be shown. ${ }^{109}$ In defending due process challenges to dress codes $^{110}$ schools have attempted to show that certain hair styles for men disrupt school activities. Courts have divided on this issue. Some have held that freedom to wear one's hair as one wishes is within the concept of liberty. ${ }^{111}$ Others have either abstained $^{112}$ or sustained the regulation as a reasonable effort to maintain order in the schools that does not infringe any constitutional right. ${ }^{113}$ The regulation's general prohibition permits an appropriately flexible approach to evaluating school rules in this area.

A school may no longer apply any sex-differentiated domicile or residency rule in providing any aid, benefit, or service to a student. ${ }^{114}$ The Secretary's introductory remarks to the proposed regulations make clear that the Department is concerned in this area with eligibility for in-state tuition fees.

objective through more narrowly drawn means. Dormitory curfews are easier to implement than would be more narrowly drawn regulations, but administrative convenience should not save a classification based on sex. See Frontiero v. Richardson, 411 U.S. 677 (1973).

10740 Fed. Reg. 24141, § 86.31(b)(5) (1975).

${ }^{108}$ E.g., Rafford v. Randle E. Ambulance Serv., Inc., 348 F. Supp. 316 (S.D. Fla. 1972).

${ }^{109}$ See text accompanying notes 49-62 supra.

${ }^{110}$ E.g., Karr v. Schmidt, 460 F.2d 609 (5th Cir. 1971), cert. denied, 409 U.S. 989 (1972); King v. Saddleback Junior College Dist. 445 F.2d 932 (9th Cir.), cert. denied, 404 U.S. 979 (1971); Crews v. Cloncs, 432 F.2d 1259 (7th Gir. 1970); Richards v. Thurston, 424 F.2d 1281 (1st Cir. 1970); Press v. Pasadena Independent School Dist., 326 F. Supp. 550 (S.D. Tex. 1971); Rumler v. Board of School Trustees, 327 F. Supp. 729 (D.S.C. 1971).

${ }^{111}$ Crews v. Cloncs, 432 F.2d 1259 (7th Cir. 1970); Richards v. Thurston, 424 F.2d 1281 (1st Cir. 1970).

112 Press v. Pasadena Independent School Dist., 326 F. Supp. 550 (S.D. Tex. 1971).

${ }^{113}$ King v. Saddleback Junior College Dist., 445 F.2d 932 (9th Cir.), cert. denied, 404 U.S. 979 (1971); Rumler v. Board of School Trustees, 327 F. Supp. 729 (D.S.C. 1971). 11440 Fed. Reg. 24141, \& 86.31(b)(6) (1975). 
"[M]any educational institutions base their determinations of eligibility for in-state tuition on domicile; applicable state law may require a married woman to take the domicile of her husband as of the date of marriage, or further require a year of residency to demonstrate domicile." 115 This kind of rule operates in favor of the female student attending school in her husband's domicile, but against the one whose school is located in her pre-marital domicile. Application of such a rule in either instance is now prohibited. HEW is clearly implementing the mandate of Title IX in this regard. A federal district court recently held that application of such a rule by Pennsylvania state universities violates the equal protection clause. ${ }^{116}$ The court was struck by the fact that there was "no rule ... to tie the residency classification of any group other than married women to the classification of someone else."117

Section $86.31(\mathrm{~b})(7)^{118}$ provides that a recipient of federal funds shall not "[a]id or perpetuate discrimination against any person by providing significant assistance to any agency, organization, or person which discriminates on the basis of sex in providing any aid, benefit, or service to students or employees ...."119 Sororities, fraternities, and youth service organizations such as the Girl Scouts and Boy Scouts successfully lobbied for the amendment exempting them from this provision. ${ }^{120}$ The amendment may have been unnecessary under the proposed regulations, the introduction to which stated:

Among the criteria to be considered in each case are the substantiality of the relationship between the recipient subject to the regulation and the other party involved, including the financial support by the recipient, and whether the other party's activities relate so closely to the recipient's educational program or activity, or to students or employees in that program, that they fairly should be considered as activities of the recipient itself. ${ }^{121}$

11539 Fed. Reg. 22229 (1974).

${ }^{116}$ Samuel v. University of Pittsburgh, 375 F. Supp. 1119 (W.D. Pa.), appeal dismissed, 506 F.2d 355 (3d Cir. 1974).

${ }^{117} I d$. at 1131 .

11840 Fed. Reg. 24141, $\$ 86.31$ (b)(7) (1975). This section was severely critized in the letters received by HEW after the announcement of the proposed regulations. N.Y. Times, Nov. 25, 1974, at 23, col. 3.

11940 Fed. Reg. 24141, § 86.31(b)(7) (1975).

${ }^{120}$ See text accompanying notes 21-30 supra.

12139 Fed. Reg. 22229 (1974). 
In explaining the final regulations, HEW writes, "[s]uch forms of assistance to discriminatory groups as faculty sponsors, facilities, administrative staff, etc., may be significant enough to render the organization subject to the ... regulation." ${ }^{22}$ The use of school facilities will involve the most difficult determinations. HEW's approach in the final regulations ${ }^{123}$ can be criticized for allowing any use of school facilities by sex-restricted organizations. The language of Title IX is absolute. The right of privacy is not at issue. Use of facilities is not restricted to discriminatory organizations whose "discrimination" might be justified by educational necessity. ${ }^{124}$ Under the approach taken in this Comment the discrimination potentially tolerated by this section cannot be justified.

The WEAL-Abzug report correctly points out that the language of section 86.31 (b)(7) prohibits recipients from assisting only those organizations that provide a benefit or service to students. ${ }^{125}$ Such single-sex organizations as the Junior Chamber of Commerce and Little League (while it remained single sex), which fall outside that qualification, could take advantage of school property and services without the intervention of HEW. ${ }^{126}$ Such a loophole in the regulations is in conflict with the broad construction of the statute suggested by Griggs and Lau.

Section 86.31 ends with the regulation of programs not operated by the recipient in which students or employees of the recipient are required or permitted to participate, including "educational consortia and cooperative employment and student-teaching assignments." ${ }^{127}$ The recipient must develop a procedure to ensure that the operator of the program takes no action in regard to students or employees which the recipient would be forbidden to take. ${ }^{128}$ If the recipient cannot ensure non-discrimination by the operator, it must dissociate itself from the program. ${ }^{129}$ This is a commendable attempt by the Department to reach less direct but nonetheless destructive discrimina: tion encountered by women in education.

122 HEW FACT SHEET 7 (June, 1975).

${ }^{123}$ Text accompanying note 122 supra.

${ }^{124}$ See text accompanying notes 44-62 supra.

125 Weal-Abzug Preliminary Analysis of Proposed Title IX Regulations, $r$ printed in 120 ConG. REC. E 4866 (daily ed. July 18, 1974).

${ }^{126} \mathrm{Id}$.

${ }^{127} 40$ Fed. Reg. 24141, § 86.31(d)(1) (1975).

${ }^{128} I d . \S 86.31$ (d)(2)(i).

${ }^{129} \mathrm{Id}$. \& 86.31(d)(2)(ii). 


\section{Housing and Other Facilities}

The housing regulations are a straightforward implementation of section 907, which allows schools to maintain separate living facilities for the sexes. ${ }^{130}$ The separate housing for females and males must be proportionate in quantity and quality, ${ }^{131}$ governed by non-discriminatory rules, and subject to the same fees. ${ }^{132}$ If the institution is involved in any way in off campus housing, it must take reasonable action to assure itself that such housing of equal quantity, quality, and cost is available to women and to men. ${ }^{133}$ The next section permits separate but comparable toilet, locker room, and shower facilities on the basis of sex. ${ }^{134}$ This interpretation comports with the rationale underlying the living facilities exception. ${ }^{135}$

\section{Integration of Courses}

The provision for equal access to educational programs or activities is controversial. "A recipient shall not provide any course or otherwise carry out any of its education program or activity separately on the basis of sex, ... including health, physical education, industrial, business, vocational, technical, home economics, music, and adult education courses." 136 The two most heatedly discussed aspects of this regulation are the possible integration of sex education and physical education classes. ${ }^{137}$ Sex education classes were specifically exempted in July, $1974,{ }^{138}$ but gym classes must be integrated.

It is difficult to reconcile the sex education exemption with a general rejection of the separate-but-equal doctrine. ${ }^{139}$ It might be argued that the right of privacy justifies this exemption. However, discussion of sexual matters is far different from the type of sexual activity protected by Griswold and Roe. ${ }^{140}$ Neither

${ }^{130} 20$ U.S.C. $\S 1686$ (Supp. II, 1972).

13140 Fed. Reg. 24141, § 86.32(b) (1975).

${ }^{132}$ Id. § 86.32(a).

${ }^{133} I d . \S 86.32(\mathrm{c})$.

${ }^{134}$ Id. $\S 86.33$.

${ }^{135}$ See text accompanying notes 32-37 supra.

13640 Fed. Reg. 24141 , \$ 86.34 (1975).

${ }^{137}$ The following letter was received during the comment period on the subject of the integration of physical education classes: "The morals of this nation are low enough now. Please don't make it worse. I pray the time will soon come again when men can be men and women can be women and each proud of what God made them." N.Y. Times, Nov. 25, 1974, at 23 , col. 5 (city ed.).

${ }^{138}$ Id.; 40 Fed. Reg. 24141, \& 86.34(e) (1975).

${ }^{139}$ See text accompanying notes $63-77$ supra.

${ }^{140}$ See text accompanying notes $32-37$ supra. 
can the concept of "unique physical characteristics" justify separate sex education classes. ${ }^{141}$ Nevertheless, HEW's toleration of separate sex education classes probably will not be challenged. According to HEW, the tentative existence of sex education classes would be threatened by a forced integration. ${ }^{\mathbf{1 4 2}}$

Integration of physical education classes is required, despite a hostile reaction to the proposed regulations and a move in the House for a physical education exemption. ${ }^{143}$ There should be no question that separate and unequal physical education programs would violate Title IX. The Project on the Status and Education of Women has compiled examples of how sex discrimination is manifested in this area.

At a prestigious private institution the women's and men's physical education departments were separate and the instructional courses available to female and male students varied considerably. For example, women could not take wrestling and men could not take self defense or volleyball.

At a southern state university female students could not take coaching courses for credit, with the result that they were not "qualified" to coach teams.

At an Ohio liberal arts college women majoring in physical education must take a service course each term. There is no similar requirement for men.

At a Pennsylvania college women must show proficiency in two sports in order to graduate. Men need only to show proficiency in one sport. ${ }^{144}$.

These examples of different treatment accorded male and female students are prohibited by the regulations. ${ }^{145}$

Separate-but-equal physical education programs should also

${ }^{141}$ See Brown, supra note 29, at 893-96.

${ }^{142}$ Action Memorandum from Director of Office for Civil Rights to Secretary of HEW, June 12, 1973, quoted in Davidson, supra note 103, at 847.

${ }^{143}$ In November, a Conference Report on H.R. 15580, making appropriations for the departments of Labor and HEW, attempted to make legislative history for Title IX to forestall HEW action in this area. Representative Edith Green expressed the position of the report: "[It] has just [been] called to my attention that one of the proposed regulations was that all physical education classes had to be integrated. Title IX was never designed to have the Federal Government get into the internal operations of how to run the classes in each and every school in the country ...."120 Cong. REc. 11106 (daily ed. Nov, 26, 1974).

144 Project on the Status and Education of Women, supra note 104, at 4-5.

14540 Fed. Reg. 24141, \& 86.34 (1975). 
be unacceptable. It was suggested above that separate-but-equal is permissible only within the narrow privacy exception or when necessary to assure equal opportunities for women. ${ }^{146}$ The exemption for separate locker facilities takes care of any disrobing problem. ${ }^{147}$ The arguments for separation that have force in competitive athletics where ability is the criterion for participation $^{148}$ are not applicable here, since students of all abilities are included in physical education classes. This is an area where the risks of inequality are great. Separate treatment discourages serious athletic interests of women and perpetuates expectations of low athletic achievement and denigration by women of their own physical abilities. ${ }^{149}$

Business and vocational classes, especially home economics and shop, are often sex segregated. No longer may a school offer separate cooking classes where girls are taught to be homemakers and boys to be chefs. ${ }^{150}$ In this area also, requirements for graduation have differed. In Robinson v. Washington, ${ }^{151}$ a female student challenged a state board of education regulation requiring one unit of home economics for girls, but not for boys, as a prerequisite to graduation. In denying the plaintiff's request for a three judge court, the judge articulated the "judicial perspective"152 from which the pursuit of sexual equality has often been viewed: "[A] judge who enjoys food is hard put to make a decision in this type of a case. Perhaps he wears his prejudice on his sleeve or in the area of his belt."153

\section{Appraisal and Counseling Materials}

Some of the more subtle and destructive sex discrimination in education takes place in the area of counseling. ${ }^{154}$ The effect

${ }^{146}$ See text accompanying notes 63-77 supra.

14740 Fed. Reg. $24141, \S 86.33$ (1975).

${ }^{148}$ See text accompanying notes 75-76 supra and notes 207-19 infra.

${ }^{149}$ See Fasteau, Giving Women a Sporting Chance, Ms., July, 1973, at 56.

"The phsysically inferior, it turns out, are not women, but any human beings who do not develop the body's potential-exactly what women have been taught not to do for centuries. Just how much that indoctrination has cost them is only now being revealed, as more and more girls challenge the age-old prejudices defining their physical capacities."

Scott, Closing the Muscle Gap, Ms., Sept., 1974, at 49.

${ }^{150}$ But see 120 Cong. Rec. $11106-07$ (daily ed. Nov. 26, 1974) (remarks of Representative Green).

${ }^{151}$ Civil No. 9576 (W.D. Wash., filed Mar. 22, 1971).

152 See Johnston \& Knapp, Sex Discrimination by Law: A Study in Judicial Perspective, 46

N.Y.U.L. REV. 675 (1971).

153 Women's Rights L. ReP., Spring, 1972, at 42.

${ }^{154}$ See 1970 Hearings, supra note 2, at 501-10, 435-50, 314-15. 
on a young girl of a counselor's saying that a given career is inappropriate for her can be irreversible. The results of a vocational guidance test that has been color coded "pink" to direct female students into careers such as homemaker, nurse, actress, and model, can determine the career choice of a potential scientist. During the hearings on discrimination against women, academicians working in this field painted a very dark picture of a girl's chances of getting adequate career guidance. ${ }^{155}$ "[T] $[$ here is some evidence, a small but growing body of research and investigation, that the individual counselor reflects-and his attitudes may even be reinforced by current training programs - the prejudices and biases of the larger society relating to woman and her educational/vocational choices."156

The proposed regulations would have changed only the most blatant discriminatory practices. A school would not have been able to use different materials for the two sexes, and tests that require or permit different treatment of students on the basis of sex would have been prohibited. ${ }^{157}$ The final regulations have been extended to prohibit discriminatory counseling itself. Because discriminatory counseling can be difficult to detect, especially by the counselors, schools are required to reexamine counseling when a single sex predominates in any particular class or program. ${ }^{158}$

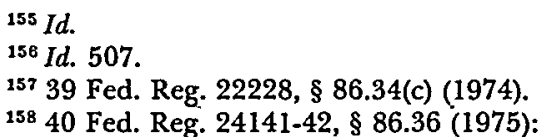

(a) Counseling. A recipient shall not discriminate against any person on the basis of sex in the counseling or guidance of students or applicants for admission.

(b) Use of appraisal and counseling materials. A recipient which uses testing or other materials for appraising or counseling students shall not use different materials for students on the basis of their sex or use materials which permit or require different treatment of students on such basis unless such different materials cover the same occupations and interest areas and the use of such different materials is shown to be essential to eliminate sex bias. Recipients shall develop and use internal procedures for ensuring that such materials do not discriminate on the basis of sex. Where the use of a counseling test or other instrument results in a substantially disproportionate number of members of one sex in any particular course of study or classification, the recipient shall take such action as is necessary to assure itself that such disproportion is not the result of discrimination in the instrument or its application.

(c) Disproportion in classes. Where a recipient finds that a particular class contains a substantially disproportionate number of individuals of one sex, the recipient shall take such action as is necessary to assure itself that such disproportion is not the result of discrimination on the basis of sex in counseling or appraisal materials or by counselors. 
Since the human element is so crucial in this area, educational institutions should probably have been required to conduct training sessions for their counselors to make them more sensitive to the necessity of approaching female students with the same open-ended career suggestions offered to males. ${ }^{159}$ Alice Fins, of the American Personnel and Guidance Association, focused the problem when relating the reaction of counselors to women with strong career ambitions: "You'll be getting married soon. Why this?" 160 No matter how neutral the materials, reinforcement of sexual stereotypes cannot be eradicated when enforcement of the regulations rests solely in the same school officials who are often unaware of their own discriminatory outlook.

\section{Financial and Employment Assistance}

The only exceptions to a complete prohibition of different treatment in the area of financial assistance relate to athletics ${ }^{161}$ and to foreign wills, trusts, or provisions by a foreign government. ${ }^{162}$ The most obvious scholarship suggested by the foreign will exemption is the prestigious Rhodes Scholarship. The only justification offered for the exemption is that the Secretary does not think the statute was intended to cover such programs. ${ }^{163}$ No theoretical reason justifies this assumption. Title VI contains no such exception. ${ }^{164}$ It is anomalous to allow one of the most coveted rewards for excellence to be denied a student on the basis of sex. Harvard and several other institutions have already nominated women who have been rejected solely on account of sex. ${ }^{165}$ Title IX does not permit such an exception to its mandate of equality.

There are no apparent loopholes in the employment guidelines. An educational institution which itself employs stu-

${ }^{159}$ See 1970 Hearings, supra note 2, at 501-10.

${ }^{160}$ Philadelphia Inquirer, Sept. 1, 1974, at 4, col. 5.

16140 Fed. Reg. 24142, \& 86.37(c) (1975):

(1) To the extent that a recipient awards athletic scholarships or grants-inaid, it must provide reasonable opportunities for such awards for members of each sex in proportion to the number of students of each sex participating in interscholastic or intercollegiate athletics.

(2) Separate athletic scholarships or grants-in-aid for members of each sex may be provided as part of separate athletic teams for members of each sex to the extent consistent with this paragraph and $\S 86.41$ of this part.

${ }^{162} I d . \$ 86.37$ (b). at 3.

${ }^{163}$ Statement by Caspar Weinberger, Secretary of HEW, HEW NEws, June 3, 1975,

16445 C.F.R. $\$ 80.3$ (b)(1)-(iii) (1970).

165 Weal-Abzug Preliminary Analysis of Proposed Title IX Regulations, reprinted in 120 ConG. REc. E 4866 (daily ed. July 18, 1974). 
dents must do so in a nondiscriminatory manner. ${ }^{166}$ If an agency, organization, or person is assisted by a recipient in making employment available to students, the recipient must assure that such employment is available to both sexes. ${ }^{167}$ If assurances are not forthcoming, the recipient may not assist the organization. ${ }^{168}$ Health and insurance benefits and services also must be provided equally for both sexes. ${ }^{169}$

\section{Marital or Parental Status}

Section 86.40 (a) prohibits the application by recipients of "any rule concerning a student's actual or potential parental, family, or marital status which treats students differently on the basis of sex." ${ }^{170}$ The regulation goes on to provide that recipients may not exclude pregnant students from their education programs or activities "unless the student requests voluntarily to participate in a separate portion of the program or activity. . .."171 A recipient may, however, require a pregnant student who desires to remain in the regular program

to obtain the certification of a physician that the student is physically and emotionally able to continue participation in the normal education program or activity so long as such a certification is required of all students for other physical or emotional conditions requiring the attention of a physician. ${ }^{172}$

If a recipient operates a separate program for pregnant students, it must be comparable with the regular program. ${ }^{173}$ Any disability related to pregnancy or recovery therefrom must be treated in the same manner as any other temporary disability with respect to student medical benefits, and pregnancy must be treated as a justification for a leave of absence for a period deemed medically necessary by the student's doctor, "at the conclusion of which the student shall be reinstated to the status which she held when the leave began."174

Although it was suggested above that pregnancy-based clas-

${ }^{166} 40$ Fed. Reg. 24142, § 86.38(b) (1975).

${ }^{167}$ Id. § 86.38(a).

${ }^{168} I d$.

${ }^{169}$ Id. \$ 86.39.

${ }^{170} \mathrm{Id}$. $\$ 86.40(\mathrm{a})$.

${ }^{171}$ Id. $\$ 86.40(\mathrm{~b})(1)$.

${ }^{172} I d . \$ 86.40(\mathrm{~b})(2)$.

${ }^{173} I d$. $\$ 86.40(\mathrm{~b})(3)$.

${ }^{174} \mathrm{Id}$. $\S \S 86.40(\mathrm{~b})(4),(5)$. 
sifications are not absolutely prohibited by Title IX and might be justified by a showing of educational necessity, ${ }^{175} \mathrm{HEW}$ has determined that exclusion or separation can be justified only under the specific conditions stated in the regulations. The Department's judgment, if challenged, will be given great deference by the courts; ${ }^{176}$ and its judgment seems sound. The expulsion of pregnant teenagers from schools is a serious problem. A 1972 HEW report comments on the policy:

Every year over 200,000 young women under 18 give birth. Usually these young women are expelled from school at the first sign of pregnancy. Out of 17,000 school districts surveyed in 1970, fewer than one third offered pregnant school-age girls any education at all. School districts that did allow students to study during pregnancy usually kept them at home or segregated them in special classes for various reasons-on moral grounds, for special protection or for convenience.

Expulsion compounds the already serious problems of teenage pregnancy. Of every 100 pregnant teenagers who leave school, 85 never come back. Rejected, cast out with a child to support and often no salable skills, these teenagers are nine times more likely to commit suicide than their peers. ${ }^{177}$

In Ordway $v$. Hargraves, ${ }^{178}$ a federal district court ordered a high school to admit a pregnant student to all classes. Medical testimony was offered to show that the student herself would be in no physical danger in attending school; on the contrary, there was a possibility of mental depression if excluded. ${ }^{179}$ The plaintiff had not disrupted school activity in any way, and the court failed to find an educational purpose for the policy. ${ }^{180}$ The principal suggested that the policy might have developed from a desire of the school officials not to appear to condone, and thus possibly increase the incidence of, pre-marital pregnancy. ${ }^{181}$ The validity of such moral censorship is open to serious question on first amendment grounds, but even if constitutionally permissi-

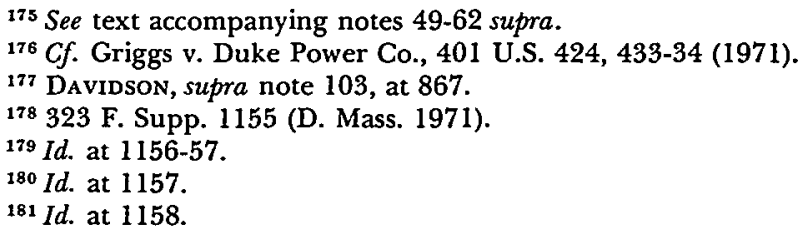

${ }^{175}$ See text accompanying notes 49-62 supra.

${ }^{176}$ Cf. Griggs v. Duke Power Co., 401 U.S. 424, 433-34 (1971).

${ }^{177}$ Davidson, supra note 103 , at 867.

178323 F. Supp. 1155 (D. Mass. 1971).

${ }^{179} \mathrm{Id}$. at $1156-57$.

${ }^{180} \mathrm{Id}$. at 1157 .

181 Id. at 1158 . 
ble, the likelihood of the feared effects is too remote to justify exclusion.

The two exceptions to the general prohibition against exclusion of pregnant students-student request and physician certification-can be justified. Since the well-being of the student should be the primary objective of educational institutions, a student's desire to separate herself from her peers during her pregnancy should be honored. A physician's judgment of medical necessity seems also to justify exclusion on this rationale, where a doctor's certificate is required of all students with other physical or emotional conditions necessitating medical attention. This general requirement prevents stigmatization of the excluded pregnant student.

\section{Competitive Athletics}

Not to have confidence in one's body is to lose confidence in oneself . . . . It is precisely the female athletes, who being positively interested in their own game, feel themselves least handicapped in comparison with the male. Let her swim, climb mountain peaks, pilot an airplane, battle against the elements, take risks, go out for adventure, and she will not feel before the world that timidity.

-Simone de Beauvoir. ${ }^{182}$

Probably the most controversial HEW regulations are those involving equalization of opportunities for men and women in the area of competitive athletics. ${ }^{183}$ Athletic associations around the country complained of the impossibility of complying with the proposed athletic regulations, ${ }^{184}$ claiming that the regulations would destroy collegiate athletics as it is known today. Such pressure exerted on HEW resulted in the weak athletic section of the final regulations.

The general prohibition of different treatment according to sex in any interscholastic, intercollegiate, club or intramural athletics $^{185}$ is significantly undermined by section $86.41(\mathrm{~b}){ }^{186}$ Whenever the activity involved is a "contact sport," the educational institution may operate separate single-sex teams, whether

${ }_{182}$ Loggia, On the Playing Fields of History, Ms., July, 1973, at 64.

18340 Fed. Reg. 24142, § 86.41 (1975).

${ }^{184}$ See Comments to the Proposed HEW Regulations, on file with the Region III Director of the Office for Civil Rights, 3535 Market St., Philadelphia, Pa. 19101.

18540 Fed. Reg. 24142, § 86.41(a) (1975).

${ }^{186} I d$. $\S 86.41(\mathrm{~b})$. 
on an intramural or competitive level. ${ }^{187}$ Where non-contact sports are involved and selection for a team is based on competitive skill, separate teams are also allowed. ${ }^{188}$ If, however, a school fields only one team in a non-contact sport, the excluded sex must be permitted to try out for the single team if athletic opportunity for the excluded sex has previously been limited. ${ }^{189}$ The only check on the discrimination permitted by this section is the general requirement that the schools provide equal athletic opportunity for members of both sexes. The regulation lists various factors relevant to a determination of the required equality of opportunity, including unequal aggregate expenditures for male and female teams. ${ }^{190}$

One threshold contention of the National Collegiate Athletic Association [NCAA] is that according to the language of the statute, sports programs should not be covered at all unless they receive direct federal funding. ${ }^{191}$ The statute provides, "[T]ermination of or refusal to grant or to continue assistance . . . shall be limited in its effect to the particular program, or part thereof, in which . . noncompliance has been ... found . . ." 192 The NCAA argues that funds cannot be refused other programs and activities in a school because of the athletic department's

${ }^{187} I d$.

${ }^{188} \mathrm{Id}$.

${ }^{189} I d$.

19040 Fed. Reg. 24142, § 86.41(c) (1975):

(c) Equal opportunity. A recipient which operates or sponsors interscholastic, intercollegiate, club or intramural athletics shall provide equal athletic opportunity for members of both sexes. In determining whether equal opportunities are available the Director will consider, among other factors:

(i) Whether the selection of sports and levels of competition effectively accommodate the interests and abilities of members of both sexes;

(ii) The provision of equipment and supplies;

(iii) Scheduling of games and practice time;

(iv) Travel and per diem allowance;

(v) Opportunity to receive coaching and academic tutoring;

(vi) Assignment and compensation of coaches and tutors;

(vii) Provision of locker rooms, practice and competitive facilities;

(viii) Provision of medical and training facilities and services;

(ix) Provision of housing and dining facilities and services;

(x) Publicity.

Unequal aggregate expenditures for members of each sex or unequal expenditures for male and female teams if a recipient operates or sponsors separate teams will not constitute noncompliance with this section, but the Director may consider the failure to provide necessary funds for teams for one sex in assessing equality of opportunity for members of each sex.

191 Statement of the NCAA on Title IX Implementation Regulations, June 26,

1974, on file with the Director of the Office for Civil Rights of Region III, 3535 Market

St., Philadelphia, Pa. 19101; N.Y. Times, Nov. 25, 1974, at 23, col. 4 (city ed.).

19220 U.S.C. § 1682 (Supp. II, 1972). 
discrimination, since the discrimination must exist in the specific program being cut off. ${ }^{193}$ Such a reading of the statute is plausible, ${ }^{194}$ but HEW takes a broader view. The Department subjects any program or activity to its requirements "if it receives or benefits from such assistance." 195

Another theory through which some organizations hope to escape the statute is that revenue-producing sports should be exempted from Title IX. Congresswoman Green reads an exemption into the statute for "intercollegiate sports financed by gate receipts . ..."196 Representative Abzug, however, warned that "making a differentiation as to the source of funds could result in unequal benefits. Thus a man's basketball team . . . could continue to travel in first-class planes while the women's basketball team ... . would have to sell cookies to pay for their transportation."197 Although there is certainly a difference between activities supported by tuition, fees, or tax dollars and those financed by gate receipts, HEW does not exempt the latter from the general prohibition against sex discrimination. It also seems improbable that many sports would fit into such an exemption since account would have to be taken of the funds that may be "'hidden' in the institution's budget in a number of ways-maintenance on the stadium, practice gyms and fields;

${ }^{193}$ Some of the stronger protests, notably by the NCAA, have provoked congressional reaction to the new regulations. On July 8, 1975, H.R. 8395 was introduced, a measure that "would allow revenue-producing sports to use their profits to maintain their own teams before diverting any profits to other men's teams and women's teams." 33 Cong. Q. WEEKLy REPT. 1484 (July 12, 1975). For further discussion of congressional efforts to block or amend the athletics regulations, see id. 1484-85. As of this writing H.R. 8395 was tentatively scheduled for hearings in September, 1975. Id. 1672 (Aug. 2, 1975).

${ }^{194}$ See Davidson, supra note 103, at 872: "Unlike Title IX of the Education Amendments of 1972, which provides for sanctions limited to the noncomplying unit or program, Executive Order sanctions may be directed at the university or college as a whole."

19540 Fed. Reg. 24128 (1975) (introductory material) (emphasis supplied). Both HEW and NCAA rely for their interpretations on Board of Public Instruction v. Finch, 414 F.2d 1068 (5th Cir. 1969). This case construes parallel language of Title VI, 42 U.S.C. $\S 2000 d-1$ (1970), which provides: "[T] its effect to the particular program, or part thereof, in which ... noncompliance has been ... found ...."

The court called for individualized consideration of the use of funds of each grant statute but noted that a program may be "so affected by discriminatory practices elsewhere in the school system that it thereby becomes discriminatory." 414 F.2d at 1079. Athletic departments may be able to argue that they have not infected the environment sufficiently to cause other programs to lose funding; the burden, however, should at least be on the recipient to demonstrate the lack of effect on other programs.

196120 Cong. REc. 11107 (daily ed. Nov. 26, 1974) (remarks of Representative Green).

' ${ }^{197}$ Id. 11108; see Project on the Status and Education of Women, supra note 104, at 13 . 
health care provided by the university health service; salaries of coaches or trainers"; athletic scholarships, etc. ${ }^{198}$

One highly questionable provision is section 86.41 (c):

Unequal aggregate expenditures for members of each sex or unequal expenditures for male and female teams if a recipient operates or sponsors separate teams will not constitute noncompliance with this section, but the Director may consider the failure to provide necessary funds for teams for one sex in assessing equality of opportunity for members of each sex. ${ }^{199}$

One might argue that the decision not to require equal aggregate expenditures is justified, because even after opportunities are equalized fewer girls will participate in competitive athletics than boys. Also some sports are more expensive to equip than others. If one sex predominates on such teams, total expenditures will be unequal. However, if the assumption is that girls are not as interested as boys and will not come out for competitive athletics in the same numbers, one must look to the reasons for this lack of interest. One major reason must be past discrimination. If all through school girls have had no training, no access to gyms and equipment, no "encouragement" to participate, it is hardly a justification for unequal expenditures that at the age of sixteen they are not as interested in sports as are boys. ${ }^{200}$

Without an equal expenditure requirement it is difficult to see how HEW will evaluate the equality of sports programs. The warning has come that an equal expenditure approach would change the face of intercollegiate athletics. ${ }^{201}$ But that is just the purpose of Title IX - to prevent the tuition, fees, and tax dollars of women students and taxpayers from being used to benefit only men. It is true that resources are finite; Title IX does not mandate spending money that does not exist. But it does demand spending available funds without discrimination on the basis of sex. Surely the Supreme Court's decision in Lau $v$. Nichols ${ }^{202}$ cost the San Francisco Unified School District some money. And Brown v. Board of Education ${ }^{203}$ changed the face of

198 Project on the Status and Education of Women, supra note 104, at 13; see

Dunkle, College Athletics: Tug-of-War for the Purse Strings, Ms., Sept., 1974, at 114.

19940 Fed. Reg. 24143, § 86.41(c) (1975).

${ }^{200}$ See Fasteau, supra note 149, at 57.

${ }^{201}$ See Comments to the Proposed HEW Regulations, on file with the Region III Director of the Office for Civil Rights, 3535 Market St., Philadelphia, Pa. 19101.

202414 U.S. 563 (1974).

${ }^{203} 347$ U.S. 483 (1954). 
education in the South. If such be the result of implementing the will of Congress, educators and athletic organizations must face that reality, and proceed forthwith to reevaluate the use of their resources with the goal in mind of developing the physical wellbeing of female and male students.

Questions about the applicability of the separate-but-equal doctrine inevitably arise in this area. The regulations allow:

separate teams for members of each sex where selection for such teams is based upon competitive skill or the activity involved is a contact sport. However, where a recipient operates or sponsors a team in a particular sport for members of one sex but operates or sponsors no such team for members of the other sex, and athletic opportunities for members of that sex have previously been limited, members of the excluded sex must be allowed to try-out for the team offered unless the sport involved is a contact sport. For the purposes of this part, contact sports include boxing, wrestling, rugby, ice hockey, football, basketball and other sports the purpose of [sic] major activity of which involves bodily contact. ${ }^{204}$

Earlier it was argued that under Title IX there should be only two justifications for separate treatment based on sex: to implement the explicit, narrow living facilities exception, or to assure equal access to certain activities. ${ }^{205}$ The narrow construction of the living facilities exception discussed earlier in the Comment does not justify separate treatment in the context of competitive athletics beyond the provision of separate locker room facilities. ${ }^{206}$ Thus, only separation necessary to assure equal access for women can be justified.

The acceptability under Title IX of fielding separate male and female teams in a particular sport should depend on the age

20440 Fed. Reg. 24142-43, $\$ 86.41$ (b) (1975). HEW explains:

Where selection is based on competitive skill or the activity involved is a contact sport, athletics may be provided through separate teams for males and females or through a single team open to both sexes. If separate teams are offered, a recipient institution may not discriminate on the basis of sex in provision of necessary equipment or supplies, or in any other way, but equal aggregate expenditures are not required. The goal of the final regulation in the area of athletics is to secure equal opportunity for males and females while allowing schools and colleges flexibility in determining how best to provide such opportunity.

HEW, Fact Sheet 6 (June, 1975).

${ }^{205}$ Text accompanying notes 74-77 supra.

${ }^{206}$ See text accompanying notes 32-37 supra. 
level of the students involved. It might be argued that there are sufficient physiological differences between the sexes not only to justify but to mandate separate-but-equal in this context. Where boys are physically stronger and larger than girls, Lau and Griggs alert us to the danger of impermissible de facto exclusion of girls from teams selected on the basis of competitive skill. ${ }^{207}$ In such a situation separate teams might be not merely acceptable, but mandatory, to prevent unequal access to competitive athletic activities. ${ }^{208}$

A full medical evaluation of the physical differences between men and women is well beyond the scope of this Comment. Yet some discussion of those differences is necessary to set standards for deciding when Title IX permits separate teams for girls and boys. Whatever the physical differences between girls and boys, they clearly increase as children get older.

[T]hroughout childhood, boys and girls are roughly similar in size, strength, and reaction times. Girls aged 9 to 12 are, if anything, larger and stronger than their male peers because their bone structure and musculature begin developing earlier and mature by age 12 or 13. Boys do not generally achieve the same stage of development until age 14,15 , or $16 .^{209}$

Medical evidence to this effect convinced the New Jersey Supreme Court to uphold a finding by the New Jersey Division on Civil Rights that girls of eight to twelve are not as a class subject to greater hazard of injury than boys and therefore must be allowed to play Little League baseball. ${ }^{210}$ It appears, then, that medical evidence does not justify athletic separation of the sexes before the junior high school level. ${ }^{211}$ If before junior high school some sports end up being predominantly of one sex because of personal preferences, there would be no violation of Title IX. But mandatory separation of the sexes in sports should not be allowed below the junior high school level unless substantial evidence indicates that failure to maintain separate teams

${ }^{207}$ See text accompanying notes 75-76 supra.

${ }^{208}$ See Fasteau, supra note 149, at 103. For analyses of the constitutional adjudication in this area and possible ways to eradicate sex discrimination in athletics, see Comment, Equality in Athletics: the Cheerleader v. the Athlete, 19 S.D.L. REv. 428 (1974); Comment, Sex Discrimination in Interschalastic High School Athletics, 25 SyrAcuse L. Rev. 535 (1974).

${ }^{209}$ Scott, supra note 149 , at 50.

${ }^{210}$ NOW, Essex County Chapter v. Little League Baseball, Inc., 127 N.J. Super. 522, 318 A.2d 33 (1974).

${ }^{211}$ Fasteau, supra note 149 , at 58. 
will, because of physical differences, result in the de facto exclusion of girls from the particular competitive sport in question.

At adolescence, physical differences increase and might well support the conclusion that separate teams should be permitted lest girls receive less benefits than boys. "[Y]oung men are on the average about 10 percent larger than young women, and their muscle mass is about twice that of girls. They perform two to four times as well in test of strength ...."212 These differences should not be overemphasized. "Evidence shows that the difference in strength between trained male and female athletes is far less than that between average or untrained men and women."213 Nevertheless, at present the gross disparity in training and conditioning and the undeniable physical differences between the sexes allow separate teams beginning at the junior high school level. The regulations, of course, permit them at every level. ${ }^{214}$

The regulations do not, however, require separate teams at any level. If a school maintains a single team in a non-contact sport without providing a separate female team in the sport, women must be permitted to try out for that single team. ${ }^{215}$ The regulations do not imply that a single, non-contact-sport team for which women may try out per se satisfies the requirements of section 86.41.216 If under an open tryout system interested women are in fact excluded, the single team arrangement may not satisfy the "equal opportunity" requirements of section 86.41(c). ${ }^{217}$ This interpretation is consistent with the general

212 Scott, supra note 149 , at 50 .

${ }^{213} \mathrm{Id}$. 49. Women are catching up to men in international competitions such as track and swimming. At the 1924 Olympic games, men's time in the 400-meter freestyle was 16 percent faster than women's; 11.66 percent faster in 1948; and only 7.3 percent faster in 1972 at Munich. Id.

21440 Fed. Reg. 24142, \$ 86.41(b) (1975).

215 Many young women have obtained injunctions to force their schools and athletic associations to allow them to try out for non-contact sports for which there was no girls' team. Brenden v. Independent School Dist., 477 F.2d 1292 (8th Cir. 1973); Reed v. Nebraska School Activities Ass'n, 341 F. Supp. 258 (D. Neb. 1972); Haas v. South Bend Community School Corp., 289 N.E.2d 495 (Ind. 1972). Contra Bucha v. Illinois High School Ass'n, 351 F. Supp. 69 (N.D. Ill. 1972). The complaints generally charged violation of fourteenth amendment rights to equal protection. In Brenden the Eighth Circuit examined the interest of the student in competing in interscholastic athletics and that of the high school in assuring that persons with similar qualifications compete among themselves, and found no "sufficient rational basis for concluding that women are incapable of competing with men in non-contact sports." $477 \mathrm{~F} .2 \mathrm{~d}$ at 1300.

${ }^{216}$ See Statement of Caspar Weinberger, Secretary of HEW, HEW News, June 3, 1975 , at 4 .

${ }^{217} 40$ Fed. Reg. 24142, § 86.41(c) (1975). 
principles suggested earlier. ${ }^{218}$ Thus, if teams theoretically open to all on a competitive basis result in exclusion of women from athletic participation, separate teams for women may be required by the regulation and are certainly required by the statute itself. $^{219}$

The general framework developed earlier ${ }^{220}$ indicates that separate contact-sport teams are justifiable in no more situations than are separate teams for non-contact sports. It might be argued that privacy should justify separating boys and girls in contact sports. As noted earlier, however, the living facilities exception does not extend this far. ${ }^{221}$

Safety is often advanced as an additional reason for sex segregation in contact sports. But, "[a]s one proponent for the integration of contact sports puts it: "If we are worried about girls' breasts and internal organs, then give them chest and belly protectors. We haven't spared our male football players any expense in that department." "222 Male athletes, no less than female, may get hurt playing certain sports. In the team selection process girls not sturdy enough to play successfully will be weeded out as are weak boys. Girls must be able to decide for themselves whether or not the rewards of playing certain sports are greater than the possibility of injury. Boys of all levels of strength and ability play all types of intra-mural sports. This situation may be compared to Weeks $v$. Southern Bell Telephone $\mathcal{\sigma}^{\circ}$ Telegraph Co. ${ }^{223}$ where the court held that calling a job strenuous would not disallow a woman from making her own decision on whether the effort of the job was worth the pay and other advantages. Women can no longer be "protected" by rules and regulations that for the most part discriminate against them.

If separate teams are justified to prevent de facto exclusion of women from competitive sports, the next question is whether female athletes should nonetheless be allowed to try out for the men's team in this separate-but-equal situation. People dedicated to equalizing opportunities for women and knowledgeable in the area of athletics disagree to such an extent on this question that judgment should be left to individual schools. Brenda Feigen Fasteau would not allow women to "compete up" because of the

\footnotetext{
${ }^{218}$ See text accompanying notes $43-48$, 75-76 supra.

219 Id.

220 See text accompanying notes 206-07 supra.

${ }^{221}$ See text accompanying notes $32-41$ supra.

${ }^{222}$ Fasteau, supra note 149, at 103.

${ }^{223} 408$ F.2d 228 (5th Cir. 1969).
} 
potential unfairness to men who could possibly make the women's team but not the men's. ${ }^{224}$ "Even more importantly, it cheats the women's team which would lose its best athletes to the male squads, thus setting women's sports back even farther."225 If an equally well-equipped girls' team is available, the question of "competing up" should be left to recipients. This is the approach apparently taken in the regulations.

Even if a difference in competitive athletic opportunities passes muster under sections $86.41(\mathrm{a})$ and (b), ${ }^{26}$ it can still be challenged under the multifactor test of section $86.41(\mathrm{c}) .{ }^{227}$ For example, if a school sponsors all-male football, basketball, boxing, and wrestling teams but no teams at all for girls, no attack can be made under sections $86.41(\mathrm{a})$ and (b). ${ }^{228}$ This arrangement, however, is clearly subject to challenge under the "equal athletic opportunity" requirement of section 86.41 (c) ${ }^{229}$ It is difficult to predict how challenges to less blatant discrimination will fare when the Director considers the ten factors listed in subsection (c).

\section{Conclusion}

Title IX's general prohibition of sex discrimination in education should be construed broadly, and the limited living facilities exception narrowly, in order to effect the remedial purpose of the statute. There is no justification for most sexbased discrimination in education. The living facilities exception should be limited to living quarters, restrooms, locker facilities, and other areas where disrobing takes place. The only justification for separation of the sexes other than privacy is to assure access to a program or activity for both male and female students. This justification will operate only in the area of competitive athletics.

The HEW regulations adhere to this analysis fairly closely. Their breadth fits in well with judicial construction of Titles VI and VII of the Civil Rights Act of 1964. In controversial areas such as athletics, however, the Department has attempted a middle course. The result is ambiguous requirements, which will

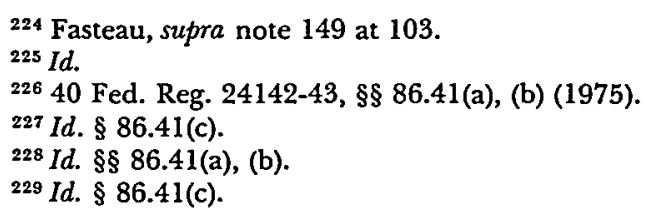


make enforcement difficult. Nevertheless, HEW's conscientious oversight of educational institutions receiving federal financial assistance should have a great influence in removing sex discrimination from the educational system. 